\title{
Comparative Study on the Pre-trial DETENTION With REFERENCE TO THE NeW Hungarian Code on Criminal Procedure ${ }^{1}$
}

\author{
Robert Bartko \& András Payrich \\ University of Győr, Deák Ferenc Faculty of \\ Law and Political Sciences, Hungary \\ drbartkorobert@gmail.com; payrich@yahoo.com
}

BARTKO, Robert; PAYRICH, András. Comparative Study on the Pre-trial Detention with Reference to the New Hungarian Code on Criminal Procedure. International and Comparative Law Review, 2017, vol. 17, no. 2, pp. 169-178. DOI 10.2478/iclr-2018-0022.

\begin{abstract}
Summary: The decision of legislating the new Criminal Procedure Code made by the Hungarian Government in 2015 was necessary with special reference to the new forms of criminality and criminal investigation. The conception of the new Code on Criminal Procedure (hereinafter: new Code) was accepted by the Government on 11 February in 2015. The directives of the conception were the followings: efficiency, rapidity, simplicity, up-to-dateness, coherency and expediency. Not only the European but also the international requirements and the Hungarian legal traditions were followed by the legislation. Two years after the mentioned decision the new Code was adopted on 13 June 2017, and it will come into force on 1 July 2018. It shall be underlined that many procedural rules will be modified or changed in the new Code. The aim of this study to highlight some changes and amendments in the field of the coercive actions with special reference to the pre-trial detention. The characteristic of the paper will be the analytical and comparative method, and it deals with not only the Act on Criminal Procedure in force (Act XIX of 1998, hereinafter: Act in force), but also the new Code (Act CX of 2017) as well.
\end{abstract}

Keywords: Criminal procedural law, Hungarian Code on Criminal Procedure, fair trial, fundamental rights, pre-trial detention, defendant, defence counsel, coercive measures.

\section{Introduction}

The Act in force passed in 1998 has been modified almost 70 times after coming into force. It shall be emphasized that the criminal procedure law is the biggest intervention in private life, which needs to be protected by constitutional guarantees. Furthermore, the rules must answer the new challenges of the criminal law as well. The rules of the criminal procedure law have special reference to the rules of law which can limit fundamental human rights. According to this

1 This study was written within the framework of the Program of Ministry of Justice on Increasing Level of the Hungarian Legal Education. 
point of view we have to stress the importance of the criminal sciences in the system of jurisdiction.

The legislation of the new Code started in 2015 has been finished in 2017. The necessity of creating a new act was realized by the Hungarian legislator. The conception of the new Code was accepted by the Government on 11 February in 2015. The directives of the conception were the followings: efficiency, rapidity, simplicity, up-to-dateness, coherency and expediency ${ }^{2}$. The new Code adopted on 13 June 2017 contains significant improvements in certain scopes however in some legal institutions it preserves the existing regulations. During the codification the legislator should take into account the European tradition as well, although the standardization of the criminal procedural law in the European Union is impossible ${ }^{3}$. There are many new regulations, which manage to significantly narrow the scope of the principle of fair trial, the rights of the defendant and the defense counsel as well. However, the mentioned modifications are specially interesting if they were able to affect the fair trial as fundamental principle in the scope of human rights. In this respect the coercive measures are of high importance. Therefore, this study is looking at the classic type of the coercive measures, the pre-trial detention. This is the most important coercive actions, namely it not only limits the fundamental human rights, but also it is applied by the judges many times during the criminal procedures. It is reinforced by the Hungarian prisons statistics as well.

1. Table: the Hungarian prison statistic on the number of the defendants held in pre-trial detention between 31 December 2009 and 31 December $2016^{4}$

\begin{tabular}{|c|c|}
\hline Date & $\begin{array}{c}\text { Number of the defendants } \\
\text { held in pre-trial detention }\end{array}$ \\
\hline 31 December 2009 & 4502 \\
\hline 31 December 2010 & 4803 \\
\hline 31 December 2011 & 4875 \\
\hline 31 December 2012 & 4888 \\
\hline 31 December 2013 & 5053 \\
\hline 31 December 2014 & 4400 \\
\hline 31 December 2015 & 3978 \\
\hline 30 June 2016 & 3803 \\
\hline 31 December 2016 & 3577 \\
\hline
\end{tabular}

2 MISKOLCZI, Barna: The Directives of the Codification on the New Criminal Procedure. In. Towards the judicial persuasion - Codification of the new Code on Criminal Procedure, Printart - Press Kft, 2015. pp. 30-43.

3 HERKE, Csongor: The Codification of the new Code on Criminal Procedure. In. Towards the judicial persuasion - Codification of the new Code on Criminal Procedure, Printart Press Kft, 2015. pp. 43-74.

4 Source: http://bv.gov.hu/sajtoszoba (Date of the download: 17 September 2017) 
For the above-mentioned reason the paper put in the centre the pre-trail detention, furthermore it will follow the view of comparison. It shall be emphasized that the codification is finished in this year, therefore the paper can deal with the text of the new Code as well. However, we have to underline that the paper highlights only the general rules on the pre-trial detention modified in the new Code, and does not deal with the rules concerned the so-called special criminal procedural regulations ${ }^{5}$.

\section{Changings in the system of rules on pre-trial detention}

\subsection{The principle of gradation}

In the course of the re-codification the procedural regulations on coercive action, changing the order of the coercive actions had a symbolic meaning. The method that the legislator proceeds from the more lenient actions toward stricter ones, highlights the application of the principle of gradation. This was already underlined by the detailed explanation of the draft on the new Code, and it is even polished in new Code as well. According to the ministerial explanation of the new Code: "the Code incorporates the principle of gradation into the general conditions of coercive actions, emphasizing the key role of this fundamental provision." The principle of gradation means that coercive measure requiring higher restrictions can be applied by the authorities only when the objective of the proceedings could not be attained by other action requiring less restrictions ${ }^{6}$.

On the basis of the mentioned principle, the legislator intends to limit applying pre-trial detention, and for this purpose, the new umbrella concept of criminal supervision has been introduced which covers the home curfew, the house arrest, the injunction (to stay away) and involve the new definition of criminal prohibition and compulsory check-in at police station. By defining the principle of gradation as a fundamental and general principle of the coercive measures, we hope that the number of the defendants held in pre-trial detention will be less in the future than now. Nevertheless to ensure for the defendant the right to defend himself at liberty is a main requirement of the UN as well ${ }^{7}$. Furthermore, we hope as well that the schematic thinking and the decision-making ${ }^{8}$ reference with the application of the mentioned coercive measure will be changed after the new Code will come into force.

5 For the special character of some criminal offences, special procedural rules inserted by the legislator into the Chapter "Special Criminal Proceedings" of the Act in force and the new Code as well. These special criminal offences are for example the crimes against the closing of border referring to the irregular migration.

6 Sec. 271 Par. (2) of the new Code.

7 HERKE, Csongor: The vicarious legal institutions of the pre-trial detention with special reference to the bail. Bírák Lapja, Hungary, 1996. vol. VI. issue 1-2. pp. 97-118.

8 SZABÓ, Krisztián: Reflections on Practice of Pre-trial detention. Curentul Juridic - Juridical Current 2014. vol. 49, no. 4. pp. 237-245. 


\subsection{The aim and the conditions of the pre-trial detention}

The aims of the mentioned coercive action are not defined exactly by the Act in force. These were created by the jurisdiction and the legal literature on the basis of the regulations on the special conditions of the pre-trial detention. These are the followings: to ensure the presence of the defendant under the criminal procedure; to prevent the frustrating, obstructing or jeopardizing the evidentiary procedure; to prevent the crime repetition.

New solution that the mentioned aims are inserted by the legislator under the Sec. 277. Par. (4) of the new Code. According to the new regulation: "the detention ${ }^{9}$ shall be made to ensure the presence of the defendant, to prevent the imposition or refusal of evidence, or to prevent crime-repetition, if, in particular

a) the nature of the offense,

b) the status and interests of the investigation,

c) the personal and family circumstances of the defendant,

d) the relationship between the defendant and the person involved in the criminal proceedings or another person,

e) the behaviour of the defendant presented before and during the criminal procedure regarding the personal liberty with an affecting judicial licenced compulsory provision desired aim restraining and criminal supervision cannot be ensured".

On the basis of the above-mentioned amendment the special conditions of the pre-trial detention will be modified by the new Code as well.

According to the Sec.129 Par. (2) of the Act in force: "the pre-trial detention of the defendant may take place in a proceeding related to a criminal offence punishable by imprisonment, and only under the following conditions:

a) the defendant has escaped, or has attempted to escape, or absconded from the court, the prosecutor or the investigating authority, or another procedure has been launched against the defendant for committing a deliberate criminal offence also punishable by imprisonment;

b) owing to the risk of an escape or hiding, or for other reason, there is reasonable cause to believe that the presence of the defendant in procedural actions cannot be otherwise ensured;

c) there is reasonable cause to believe that if left at liberty, the defendant would frustrate, obstruct or jeopardise the evidentiary procedure, especially by means of influencing or intimidating the witnesses, or by the destruction, falsification or secretion of physical evidence or documents;

9 The name of pre-trial detention, in order to be more specific when identifying the coercive action, changes to detention. 
d) there is reasonable cause to believe that if left at liberty, the defendant would accomplish the attempted or planned criminal offence or commit another criminal offence punishable by imprisonment."

The mentioned conditions ${ }^{10}$ will be polished by the Sec. 276 Par. (2) of new Code and will be collected in several groups relating to the different aims of this coercive measure. The detention of the defendant may take place under the under-mentioned conditions:

a) to ensure to presence of the defendant, if

a) the defendant has escaped, or has attempted to escape, or absconded from the court, the prosecutor, or the investigating authority, or

ab) there is reasonable cause to believe that the defendant will be inaccessible during the criminal procedure, especially the defendant would escape or abscond;

b) to prevent the obstructing and jeopardising the evidentiary procedure, if

ba) for the reason of frustrating the evidentiary procedure, person involved in the criminal proceedings or another person was intimidated or influenced, or evidences and documents and electronic data was destructed, falsified or secreted by the defendant, or

bb) there is reasonable cause to believe that the defendant would endanger the evidentiary procedure, especially the defendant would intimidate or influence person involved in the criminal procedure or another person, or would destruct, falsify or secrete evidences, documents and electronic data;

c) to prevent the crime-repetition, if

ca) the defendant continued to commit the criminal offence made the subject of the investigation after the defendant was suspected, or the defendant was suspected of another criminal offence punishable by imprisonment, or

ca) there is reasonable cause to believe that the defendant would accomplish the attempted or planned criminal offence, or would continue to commit the criminal offence made the subject of the investigation, or would commit another criminal offence punishable by imprisonment.

The new Code changes the ways of thwarting, encumbering or endangering the process by regulating not only influencing or threatening the witness, but also that of other persons participating in the process. It may occur that the defendant applies pressure to a person supporting the victim in order to influence the content of the statement the victim makes. The differences between the rules of the Act in force and the new Code are summarized in the following table.

10 About the conditions can be found further information in: HERKE, Csongor: Apocryphal grounds of the detention. Belügyi Szemle, Hungary, 2001. vol. 12. pp. 83-92. 
Table 2. Differences concerning the conditions of the detention between the Act in force and the new Code

\begin{tabular}{|c|c|}
\hline Act in force & new Code \\
\hline $\begin{array}{c}\text { condition of the detention if the defend- } \\
\text { ant has escaped or attempted to escape, } \\
\text { or absconded from the authorities }\end{array}$ & $\begin{array}{c}\text { the main condition of the detention if } \\
\text { the defendant will be inaccessible, and } \\
\text { the other cases are only examples }\end{array}$ \\
\hline $\begin{array}{c}\text { influencing or intimidating are } \\
\text { conditions of the detention but } \\
\text { only towards the witnesses }\end{array}$ & $\begin{array}{c}\text { this case will be extended with any person } \\
\text { involved in the criminal procedure, and } \\
\text { another person untouched in the criminal } \\
\text { procedure when the defendant would } \\
\text { influence or intimidate him or her }\end{array}$ \\
\hline $\begin{array}{c}\text { it does not insist on the impor- } \\
\text { tance of the continuation to com- } \\
\text { mit the criminal offence made the } \\
\text { subject of the investigation }\end{array}$ & $\begin{array}{c}\text { the condition will be extended with } \\
\text { the mentioned criminal offence } \\
\text { made the subject of the procedure }\end{array}$ \\
\hline \multicolumn{2}{|c|}{}
\end{tabular}

\subsection{The objective deadline of the pre-trial detention}

According to the ministerial explanation the duration and deadline of the arrest are regulated in the same way as the rules in force: before the indictment may be ordered, it may continue to be one month and may be extended by three months after one year from the date of the order. However, it shall be underlined that the pre-trial detention restricts the fundamental human right of the defendant, therefore it is necessary to declare the deadline of this coercive measure. On this basis fundamental procedural principles are declared by the European Convention on Human Rights as well ${ }^{11}$.

Both Act deal with this question however, differences can be found in them. According to the Sec.132 Par. (3) and (3a) of the Act in force:

„Pre-trial detention is terminated

(a) if the duration thereof exceeds one year and the subject of the procedure is a criminal offence punishable by imprisonment not longer than three years,

(b) if the duration thereof exceeds two years and the subject of the procedure is a criminal offence punishable by imprisonment not longer than five years, c) if the duration thereof, in cases beyond points a) and b), exceeds three years,

except the pre-trial detention ordered or sustained after the sentence of the court or if the procedure is in progress is before the court of appeal on the third instance or a repeated procedure is in progress owing to a repeal in the case.

11 BUTMAN, László: Legal conditions of the detention in the European fundamental rights. Bírák Lapja, Hungary, 1996. Vol. VI. issue 3-4. pp. 176-196. 
(3a) The pre-trial detention is not terminated if the subject of the procedure is a criminal offence punishable by imprisonment for a term up to fifteen years or life imprisonment by law."

Related to the mentioned regulations it shall be emphasized that regulations on the objective deadline of the pre-trial detention was modified by the Act CLXXXVI of 2013. The Hungarian legislator repealed this deadline with reference to the crimes punishable by imprisonment for a term up to fifteen years or life imprisonment by law /Sec. 132 Par. (3a)/. Before this modification the objective deadline of the pre-trial detention was four years in case of the above-mentioned crimes. It shall be emphasized that this amendment entered into force on 19 November 2013. It shall be stressed that the other regulations modified by the above-mentioned act were into force on 1 January 2014. Unfortunately, the reason of the earlier entering into force was a concrete criminal case (socalled: The Case of Ároktö ${ }^{12}$ ). Actually - so to say responding to the events of the above-mentioned criminal case - the regulations on the objective deadline of the pre-trial detention were modified by the Hungarian legislator. Namely if the Hungarian legislator had enacted all of the above-mentioned regulations of the Act at same time (this time was 1 January 2014), the court should have released the defendants in the Case of Ároktö regarding that the procedural regulations on the objective deadline of the pre-trial detention were valid in the time of this criminal case $^{13}$. Unfortunately, with this amendment an erosion has been started concerning the criminal procedural principles ${ }^{14}$ and the new Code does not make a change in it.

According to the Sec. 298. Par. (1)-(2) of the new Code:

"(1) The detention lasts up to

a) one year if the subject of the criminal procedure is a criminal offence punishable by imprisonment not longer than three years,

b) two years if the subject of the criminal procedure is a criminal offence punishable by imprisonment not longer than five years,

c) three years if the subject of the criminal procedure is a criminal offence punishable by imprisonment not longer than ten years,

d) four years if the subject of the criminal procedure is a criminal offence punishable by imprisonment for more than ten years.

12 Ároktö is a little city in Hungary where was a criminal gang according to the indictment, and this criminal gang committed a lot of crimes of high priority.

13 BARTKÓ, Róbert: The principle of fair trial with special reference to the temporal scope of the Hunarian Act on Criminal Procedure. In. Daniela Cickanová, Ivana Hapcová, Vladislav Micatek (edit.): BRATISLAVA LEGAL FORUM 2015. Collection of Papers from the International Academic Conference Bratislava Legal Forum 2015 organised by the Comenius University in Bratislava, Faculty of Law, Slovakia, 2015. pp. 572-575.

14 About this problem further information can be found in: BARTKÓ, Róbert: Changing on the Principle of Legality in the Hungarian legal Fight against the Irregular Migration. International Journal of Current Advanced Research Vol. 6. issue 8. 2017. pp. 5352-5354. 
(2) The duration in paragraph (1) does not apply

(a) if the criminal offence punishable by life imprisonment by law,

(b) detention ordered or sustained after the sentence of the court,

(c) if the subject of the procedure is an appeal submitted against the decision

on repeal of the court of appeal on the second or on the third instance, or

(d) a repeated procedure is in progress owing to a repeal in the case."

The differences can be found not only under the regulation referring to the general deadline, but also under the exceptions as well, are summarized in the following table.

Table 3. Differences concerning the objective deadline of the detention

\begin{tabular}{|c|c|}
\hline Act in force & new Code \\
\hline $\begin{array}{c}\text { if the criminal offence made the subject } \\
\text { of the procedure punishable by impris- } \\
\text { onment for a term up to five years, } \\
\text { the deadline uniformly three years }\end{array}$ & $\begin{array}{c}\text { this case will be reduced by the new } \\
\text { pode to two cases: if the criminal offence } \\
\text { punishable by imprisonment for a term } \\
\text { up to five years, but not longer than } \\
\text { ten years, the deadline is three years, } \\
\text { and if the criminal offence punish- } \\
\text { able by imprisonment for a term up to } \\
\text { ten years, the deadline is four years }\end{array}$ \\
\hline $\begin{array}{c}\text { The deadline is repealed by the Act if the } \\
\text { criminal offence punishable by impris- } \\
\text { onment for a term up to fifteen years }\end{array}$ & $\begin{array}{c}\text { this rule will be deleted by the new Code } \\
\text { a new exception will appear in the } \\
\text { new Code concerning the changing of } \\
\text { the procedural rules (if the subject is } \\
\text { an appeal submitted against the deci- } \\
\text { sion on repeal of the court of appeal } \\
\text { on the second and on third instance) }\end{array}$ \\
\hline
\end{tabular}

2.4 The relationship between the prosecutor and the defendant and the defence counsel concerning the motion on pre-trial detention

It shall be underlined that before 1 January 2014 neither the defendant nor the defence counsel had access the evidence which constituted the basis of the motion on pre-trial detention made by the prosecutor. Namely the defendant and the defence counsel appeared in the closed session of the investigating judge without having previous knowledge of the evidence to the matter to be discussed, only the motion. For this reason, they were not able to advance detailed arguments against the proposal of the prosecutor. But from 1 January 2014 according to the Sec. 211 Par. (1) of the Act in force the prosecutor shall make available to the defendant and the defence counsel - before the closed session of the investigating judge - not only the motion but also all of the evidence, which the motion is based on. Hereby the Hungarian legislator made possible - following the regulations of directive 2012/13/EU of the European Parliament 
and of the Council on the right to information in criminal proceedings - that the right to defence can get real content before the decision of the investigating judge. Fortunately the right to have previous knowledge of the evidences which the motion of the pre-trial detention is based on is ensured by the new Code for the defendant and the defence counsel as well under the Sec. 470 Par. (1)-(3). However, a new regulation will be inserted by the new Code referring to the mentioned rule. According to the Sec. 470 Par. (3) of the new Code the previous knowledge of the evidences shall be guaranteed by the prosecutor in due time which cannot be shorter than one hour before the time of the closed session of the investigating judge.

\section{Final remarks}

It shall be emphasized that the new legal institution and the new legal solutions regulated in the new Code will require the changing of the legal mind. A lot of new, up-to-date and acceptable legal solution can be found in the Code, however we have mixed feelings with reference to the coercive measures ${ }^{15}$. Namely it can often appear that the rapid legislation or codification serves mainly political aims and the practice shows the anomalies in the system of the regulations. The new Code will come into force on 1 July 2018, therefore the legal practice does not have time enough to prepare for the application of the new regulations. We hope that the mentioned time will be modified by the legislator, and the legal community (judges, investigating authorities, public prosecutors, defence counsels) will have time enough to write up those guide-lines which can help for them in the course of the application of the new Code. Hungary is a state of the rule of law, and aims to meet the requirements of the European Union, the human rights standards and our international commitment, therefore we are sure that the Hungarian legal community will be able to apply the new regulations in the modern criminal procedural framework created by the new Code.

\section{References}

BARTKÓ, Róbert: Changing on the Principle of Legality in the Hungarian legal Fight against the Irregular Migration. International Journal of Current Advanced Research Vol. 6. issue 8. 2017. pp. 5352-5354.

BARTKÓ, Róbert: The principle of fair trial with special reference to the temporal scope of the Hunarian Act on Criminal Procedure. In. Daniela Cickanová, Ivana Hapcová, Vladislav Micatek (edit.): BRATISLAVA LEGAL FORUM 2015. Collection of Papers from the International Academic Conference Bratislava Legal Forum 2015 organised by the Comenius University in Bratislava, Faculty of Law, Slovakia, 2015. pp. 572-575.

BUTMAN, László: Legal conditions of the detention in the European fundamental rights. Bírák Lapja, Hungary, 1996. Vol. VI. issue 3-4. pp. 176-196.

15 RÓTH, Erika: The changing system of the coercive measures and the detailed rules. Ügyészek Lapja, Hungary, 2016. vol. 23, issue 3-4. pp. 39-51. 
ICLR, 2017, Vol. 17, No. 2.

HERKE, Csongor: The Codification of the new Code on Criminal Procedure. In. Towards the judicial persuasion - Codification of the new Code on Criminal Procedure, Printart - Press Kft, 2015. pp. 43-74.

HERKE, Csongor: The vicarious legal institutions of the pre-trial detention with special reference to the bail. Bírák Lapja, Hungary, 1996. vol. VI. issue 1-2. pp. 97-118.

HERKE, Csongor: Apocryphal grounds of the detention. Belügyi Szemle, Hungary, 2001. vol. 12. pp. 83-92.

MISKOLCZI, Barna: The Directives of the Codification on the New Criminal Procedure. In. Towards the judicial persuasion - Codification of the new Code on Criminal Procedure, Printart - Press Kft, 2015. pp. 30-43.

Review of the Prison Statistic - Journal of the Hungarian Prison Service Headquarters / ISSN 2416-0881/, Hungary, 2016. vol 2., pp 1-33.

Review of the Prison Statistic - Journal of the Hungarian Prison Service Headquarters / ISSN 2416-0881/, Hungary, 2017. vol 1. pp. 1-33.

RÓTH, Erika: The changing system of the coercive measures and the detailed rules. Ügyészek Lapja, Hungary, 2016. vol. 23, issue 3-4. pp. 39-51.

SZABÓ, Krisztián: Reflections on Practice of Pre-trial detention. Curentul Juridic - Juridical Current 2014. vol. 49, no. 4. pp. 237-245. 